\title{
New perspectives on antibiotic resistance
}

\author{
Florica Sandru'1,2, Adelina Popa', Mihai Cristian Dumitrascu' ${ }^{2,3}$, Aida Petca ${ }^{2,4}$, \\ Razvan-Cosmin Petca ${ }^{2,5}$, Carmen Cristina Draghici', Ana Maria Alexandra Stanescu ${ }^{2}$ \\ ${ }^{1}$ Department of Dermatology, "Elias" University Emergency Hospital, Bucharest, Romania \\ 2"Carol Davila" University of Medicine and Pharmacy, Bucharest, Romania \\ ${ }^{3}$ Department of Obstetrics and Gynecology, University Emergency Hospital, Bucharest, Romania \\ ${ }^{4}$ Department of Obstetrics and Gynecology, "Elias" University Emergency Hospital, \\ Bucharest, Romania \\ ${ }^{5}$ Department of Urology, "Prof. Dr. Th. Burghele" Clinical Hospital, Bucharest, Romania
}

\begin{abstract}
Antibiotics are considered to be "miracle" drugs responsible for controlling microbial infections. Over the years, multiple varieties of antibiotics have been used, both for therapeutic and prophylactic purposes, especially in the industrial and food sector. This has caused microorganisms resistant to different classes of antibiotics. The purpose of this article is to present the phenomenon of antibiotic resistance, but also the challenges that current society faces after the excessive use of these drugs.
\end{abstract}

Keywords: antibiotics, resistance, microorganisms

\section{INTRODUCTION}

Antibiotics can be referred to as substances that have the ability to inhibit bacterial growth and replication. Not only are the bacteria harmful to the human body, but their destruction is the target of antibiotics. The rest, fungi and viruses are treated with antifungals and antivirals (1).

The introduction of antibiotics into medical use has revolutionized the treatment of infectious pathologies. The beginning of the antibiotic era is linked to two names: Alexander Fleming and Paul Ehrlich. Between 1945 and 1972, life expectancy increased, on average, 8 years after the introduction of antibiotic treatment in infections that until then were considered life-threatening. The discovery of antibiotics was considered a great achievement for that period, by their effect of destroying the bacteria without affecting the host organism. Fleming was the first to mention penicillin resistance when used in small quantities and for a short time (2).

Antibiotics, whether cytotoxic or cytostatic to microorganisms, allow the human body to trigger and unleash its natural defense mechanisms, such as activating the immune system and eliminating the causative factor. They usually act by inhibiting protein synthesis, deoxyribonucleic acid, ribonucleic acid or by the action of an agent on the bacterial membrane (3).

Millions of tons of antibiotics have been produced in the last 6 decades, and the increased need for their use has led, due to their irresponsible use, to the emergence of drug resistance, which is a real problem today. The causes of the emergence of the global resistance to antibiotics are represented by the overcrowding of the planet, the global migration, the increase of the use of antibiotics in the food industry, the poor hygiene but also a deficient health system. With the improvement of technology, more and more people are now informed about the negative effects of antibiotic-resistant germs and have taken proactive measures to improve the problem by moderately using these drugs. Until a few years ago, antibiotics could be bought without a prescription, being the predominant factor implicated in the occurrence of this phenomenon $(4,5)$. 


\section{MECHANISM OF ANTIBIOTIC RESISTANCE}

Antibiotic resistance develops when that drug loses its ability to inhibit bacterial growth effectively, thus making the bacteria "resistant" and continuing cell multiplication, thus requiring higher doses of antibiotic than the maximum recommended value to have the desired effect. The occurrence of this phenomenon may be the result of a natural selection process whereby certain bacteria have a lower or higher degree of resistance to certain drugs. These microorganisms have developed certain mechanisms to withstand the antimicrobial effect of antibiotics. Normally, most antibiotics are produced by saprophytic bacteria or fungi, few of which are completely synthetic such as fluoroquinolones or sulfonamides. Therefore, these microorganisms have developed defensive mechanisms as alterations of the target mechanism, inhibition of the penetration or distribution of the antibiotic at the target organism or the production of enzymes that play a role in inhibiting the antimicrobial effect of antibiotics $(6,7)$. The main cause of this phenomenon is the excessive use of antibiotics, which have the role of destroying the bacteria sensitive to the substance, but also of multiplying resistant bacteria. Even if overuse of antibiotics is discouraged, they are one of the over-thecounter classes of drugs (6) (e.g.: Fig. 1).

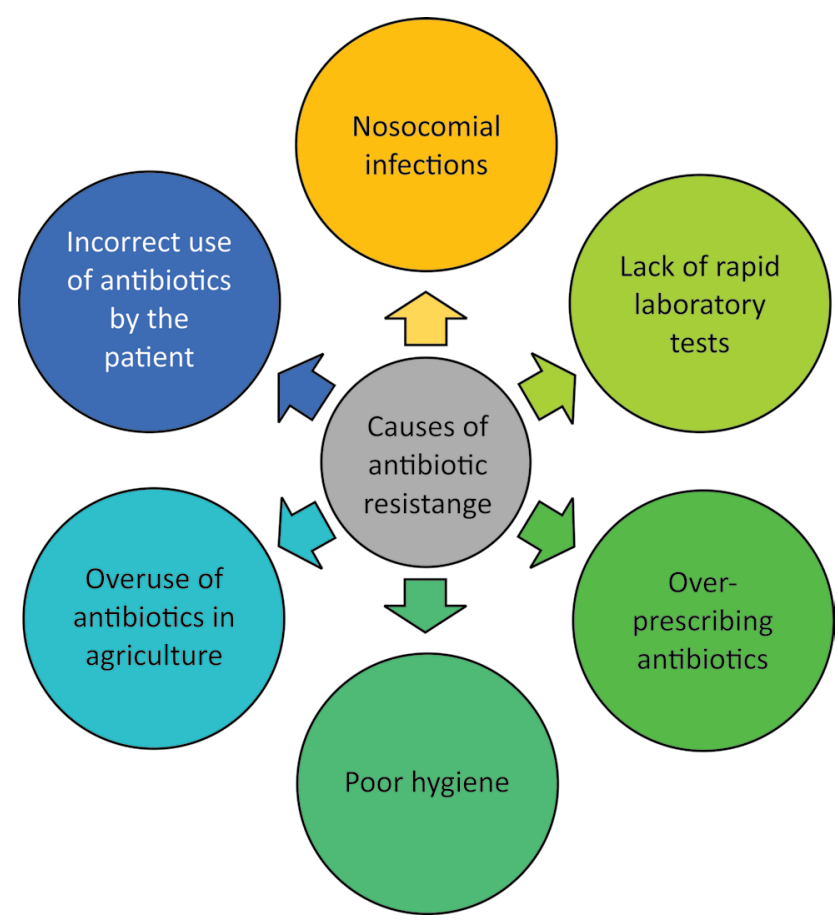

FIGURE 1. Causes of the phenomenon of antibiotic resistance

Thus, a study in Thailand showed that the administration of ampicillin and tetracycline in the treatment of non-holistic infectious diarrhea is no longer effective, although it was the first-line treatment in the past (8). Another study conducted in Bangladesh highlighted the efficacy of this treatment in patients with non-diarrheal diarrhea. Another example is sulfonamide, the use of which has proven to be a therapeutic challenge due to the development of resistance mechanisms right from the beginning of their introduction on the drug market (9). The resistance of some bacteria to sulfonamides has been reported since 1930, pointing out that the same mechanisms involved in the induction of resistance are still present. Resistance to methicillin, introduced in 1961 for the treatment of staphylococcal gold infection, has been reported to be rapid after the introduction of this drug on the market (10). Fluoroquinolones, even though they were created for the treatment of gram-negative bacilli, have become resistant to these bacteria after they have also been used to treat infections with gram-positive bacilli (11). Recently, the emergence of vancomycin-resistant golden Staphylococcus has been cited, almost 44 years after the introduction of vancomycin into current practice (12). Also, antibiotics used in the food industry are often similar to those used in human pathology, causing the transmission of antibiotic-resistant germs between animals and humans $(13,14)$. In most countries, livestock farms use antibiotics in water and their nutrition, as well as parenteral nutrition, being responsible for the induction and migration of pathogens resistant to certain antibiotics (15).

\section{CURRENT ASPECTS OF ANTIBIOTIC RESISTANCE}

Antibiotics have been designed to be able to destroy the bacteria that invade the host organism. At the same time, bacteria have the ability to stimulate the emergence of the resistance process through gene mutations. Bacteria have the ability to transfer genetic material from one to another, pointing out that natural selection is not the only mechanism involved in the emergence of the resistance phenomenon. Thus, the spectrum of antibiotics used in the hospital units, for the treatment of nosocomial infections, determines the stimulation of this phenomenon (16). Antibiotics have the ability to remove most bacteria from a colony. However, there may be bacterial colonies that have gene mutations that make them resistant to certain classes of antibiotics (17). The emergence of antibiotic-resistant bacteria was mainly associated with the degree of antibiotic use. Another incriminating aspect was related to the incorrect use of the prescribed treat- 
ment, causing the appearance of bacteria resistant to several classes of antibiotics (18). For example, staphylococcus resistance was determined by chromosomal mutations, ineffective in transporting aminoglycosides to bacteria, but also to enzymatic modifications (19). A single drug cannot induce a single antibiotic resistance. For example, tetracycline resistance may cause resistance to its different subclasses (oxytetracycline, chlortetracycline, doxycycline, minocycline) (20).

The emergence of antibiotic resistant microorganisms is a problem of global interest, responsible for inducing life-threatening infections. The World Health Organization has sounded an alarm signal suggesting the emergence of resistant bacteria, capable of inducing severe infections and even death if we fail in the fight with antibiotic resistance. In Europe, over 25,000 deaths from infections with multi-drug resistant bacteria are reported annually (21). The costs resulting from these pathologies lead to the further increase of the health services and to the decrease of the productivity of the medical document. Studies have shown a correlation between increased use of antibiotics and the emergence of antibiotic-resistant microorganisms, while moderate use of these drugs is responsible for the decrease in this phenomenon. Moreover, the re-administration of an antibiotic accelerates the process of inducing the resistance of microorganisms to antibiotics. Thus, the antibiotics used excessively cause the bacteria to develop their adaptability mechanisms, suggesting the important role of the individual and society in inducing and maintaining this process $(19,22)$.

\section{CONCLUSIONS}

The phenomenon of antibiotic resistance is equally developed in every continent. Despite the measures taken by the World Health Organization, the use of antibiotics in humans, animals and in agriculture is constantly increasing. This aspect has led to the appearance of significant financial deficits highlighted mainly in the health system by increasing the costs regarding the measures to control the infections. Leaders in the healthcare system need to establish urgent measures regarding national and international control over the use of antibiotics to stop over-use of these drugs.

\section{Acknowledgement}

All authors have the same contribution.

\section{REFERENCES}

1. Davies J, Davies D. Origins and Evolution of Antibiotic Resistance. Microbiol Mol Biol Rev. 2010 Sep; 74(3): 417-433.

2. Aminov RI. A brief history of the antibiotic era: Lessons learned and challenges for the future. Front Microbiol. 2010;1:134.

3. Levy SB, Marshall B. Antibacterial resistance worldwide: causes, challenges and responses. 2004;10(12 Suppl):S122-9.

4. Levy SB. The challenge of antibiotic resistance. Sci Am. 1998; 278(3):46-53.

5. Grigoryan L, Burgerhof JG, Haaijer-Ruskamp FM, et al. Is selfmedication with antibiotics in Europe driven by prescribed use? J Antimicrob Chemother. 2007; 59(1):152-156.

6. Aslam B, Wang W, Arshad Ml, et al. Antibiotic resistance: a rundown of a global crisis. Infect Drug Resist. 2018; 11:1645-1658.

7. Mircescu D, Totan A, Stanescu II, et al. Periodontal disease and systemic health. Revista Medicală Română 2019; LXVI(3):195-199.

8. Hoge CW, Gambel JM, Srijan A, et al. Trends in antibiotic resistance among diarrheal pathogens isolated in Thailand over 15 years. Clin Infect Dis. 1998; 26(2):341-345.

9. Stefani C, Grajdeanu IV, Serban B, et al. Scabia și boala Lyme implicații în timpul sarcinii. Revista Medicală Română 2019; LXVI(2):122-125.

10. Rahman AE, lqbal A, Hoque DME, et al. Managing Neonatal and Early Childhood Syndromic Sepsis in Sub-District Hospitals in Resource Poor Settings: Improvement in Quality of Care through Introduction of a Package of Interventions in Rural Bangladesh. PLOS ONE 12(1): e0170267.

11. Jevons MP. "Celbenin"-resistant staphylococci. Br Med J. 1961; 1:124-125

12. Lowy FD. Antimicrobial resistance: The example of Staphylococcus aureus. J Clin Invest. 2003;111:1265-1273.

13. Appelbaum $P$. The emergence of vancomycin intermediate and vancomycin resistant Staphylococcus aureus. Clin Microbiol Infect. 2006;12:16-23.

14. Stănescu AMA, Grajdeanu IV, Serban B, et al. Importanța supradiagnosticării în medicina de familie. Cum minimalizăm riscurile? Revista Medicală Română 2019; LXVI(1):29-33.

15. McEwen SA, Fedorka-Cray PJ. Antimicrobial use and resistance in animals. Clin Infect Dis. 2002; 34:93-106.

16. Witte W. Medical consequences of antibiotic use in agriculture. Science. 1998; 279:996-997.

17. Stănescu AMA, Grajdeanu IV, Stefani C, Șerban B, Diaconu CC. Eficacitatea și efactele adverse ale terapiilor complementare și alternative în acnee. Practica Medicală 2019; 14,1(64):34-39.

18. Alanis AJ. Resistance to antibiotics: Are we in the post-antibiotic era? Arch Med Res. 2005; 36:697-705.

19. Zaman SB, Hussain MA, Nye R, et al. A Review on Antibiotic Resistance: Alarm Bells are Ringing. Cureus. 2017; 9(6):e1403.

20. Stănescu AMA, Grăjdeanu IV, Bratu OG, et al. Problematica comunicării medic-pacient în practica medicală. Modalități de abordare a pacientului în cazurile complicate. Revista Medicală Română 2018; LXV(2):98-101.

21. Chopra I, Roberts M. Tetracycline antibiotics: Mode of action, applications, molecular biology, and epidemiology of bacterial resistance. Microbiol Mol Biol Rev. 2001; 65:232-260.

22. Freire-Moran L, Aronsson B, Manz C, et al. Critical shortage of new antibiotics in development against multidrug-resistant bacteria - Time to react is now. Drug Resist Updat. 2011; 14:118-124. 